\section{Ring chromosome 1 associated with radial ray defect}

The patient was born at 38 weeks' gestation and was very small, weight $1.48 \mathrm{~kg}$ (approximately $1 \mathrm{~kg}$ below the $3 \mathrm{rd}$ centile), length $42 \mathrm{~cm}$ ( $5 \mathrm{~cm}$ below the $3 \mathrm{rd}$ centile), and head circumference $28 \mathrm{~cm}$ ( $4 \mathrm{~cm}$ below the $3 \mathrm{rd}$ centile). She had an abnormal face with a sloping forehead, prominent nose, thin lips, and micrognathia. The hands were radially deviated, with absent first metacarpals, and hypoplastic thumbs (fig 1). The right thumb was attached by only a narrow pedicle and the left had no tendinous attachment. Both were biphalangeal. Her subsequent development has keen retarded and at a recent assessment at 2 years 3 months she was functioning at a 9 month level. She remained very small, with a weight of $6 \mathrm{~kg}$, length $68 \mathrm{~cm}$, and head circumference $38.5 \mathrm{~cm}$, being respectively $4 \mathrm{~kg}, 12 \mathrm{~cm}$, and $7 \mathrm{~cm}$ below the $3 \mathrm{rd}$ centile.

$\mathrm{G}$ and $\mathrm{C}$ banding was done on 72 hour cultured lymphocytes. Most cells had a ring chromosome 1, in which no loss or gain of chromosomal material could be detected (fig 2). In a few cells, variant rings were seen. Some showed a duplication of bands $1 \mathrm{q} 24 \rightarrow 44$, some had a very long dicentric chromosome, which appeared to be a duplicated and broken ring, and in some cells

Received for publication 4 February 1984. Accepted for publication 1 March 1984.

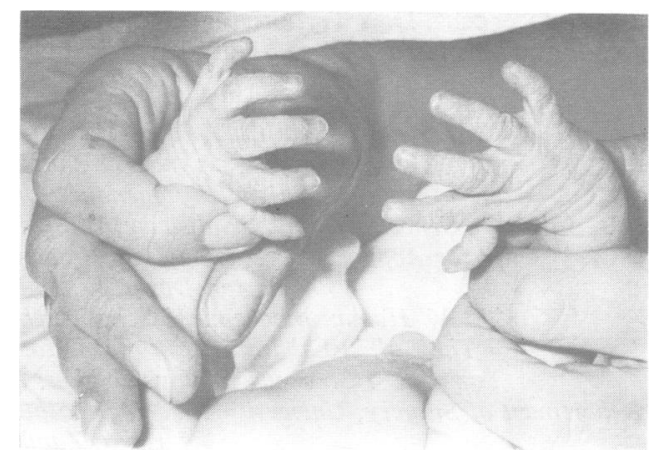

FIG 1 The baby's hands.

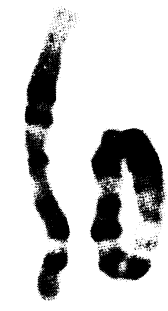

FIG 2 The ring 1 and the normal chromosome 1 .

a much smaller ring was seen. The parents' chromosomes were normal and $\mathrm{C}$ banding was not informative as to the parental origin of the ring.

A ring chromosome 1 is very rare, only four cases having $\vec{f}$ been previously recorded. ${ }^{1}$ The constant phenotypic

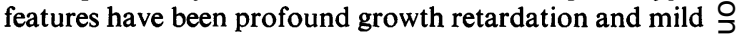
mental retardation. In none has a consistent loss of chromosomal material been detected. Thus, these cases may be examples of the 'general ring syndrome', as proposed by Coté et $a l,{ }^{2}$ in which telomere-to-telomere fusion occurs, with mechanical disruption of mitosis being the process which determines phenotypic $\vec{\theta}$ abnormality.

\section{R J M Gardner, R M Grindley, W E Chewinc\$ AND J E CLARKSOD Department of Paediatrics and Child Healt University of Otago, and Department of Laboratory Services, Dunedin Hospital, Dunedin, New Zealand.}

\section{References}

1 Kjessler B, Gustavson KH, Wigertz A. Apparently nondeleted ring-1 chromosome and extreme growth failure in a mentally retarded girl. Clin Genet $1978 ; 14: 8-15$.

2 Coté GB, Katsantoni A, Deligeorgis D. The cytogenetic and clinical implications of a ring chromosome 2. Ann $\overrightarrow{0}$ Genet (Paris) $1981 ; 24: 231-5$.

Correspondence and requests for reprints to $\operatorname{Dr} \mathbf{R} \mathbf{J} \mathbf{M}$ Gardner, Department of Paediatrics and Child Health, University of Otago, PO Box 913, Dunedin, New Zealand 